\title{
A first approach to 2,2'-bipyridine thiacrown ethers containing bisamide groups ${ }^{1}$
}

\author{
Danuta Branowska, Justyna Lawecka, Waldemar Wysocki, and Andrzej Rykowski* \\ University of Podlasie, Department of Chemistry, 08-110 Siedlce, Poland \\ E-mail: rykowski@ap.siedlce.pl
}

Dedicated to the $80^{\text {th }}$ birthday of Professor Henk C. van der Plas

\begin{abstract}
Synthesis of thiamacrocyclic bisamides incorporating bipyridine subunit tethered to poly(ethylene glycol) chains has been achieved using sequential S-transalkylation-amidification of 2,2'-bipyridine alkyl sulfides.
\end{abstract}

Keywords: Bisamides, macrocyclization reaction, [4+2] cycloaddition, S-transalkylation

\section{Introduction}

Macrocyclic ligands containing amide functional groups play an important role in coordinationand supramolecular chemistry. The amide functionality exhibits a dual complexating feature $(\mathrm{C}=\mathrm{O}$ and $\mathrm{N}$ or $\mathrm{NH})$, thus meaning that amide-based molecular receptors can bind metal, neutral molecules and organic cations and anions as well. ${ }^{2}$ Some of them are used as biologically interacting substrates ${ }^{3}$ and their optically active forms are applied to chiral recognition processes. ${ }^{4}$ There are a number of macrocycles which in addition to amide functional groups contain other elements and/or heteroaromatic rings. For example, a 14-membered ligand containing two amide and two sulfur donor groups was shown to be selective for $\mathrm{Pd}(\mathrm{II})$ and $\mathrm{Pt}(\mathrm{II})$ over $\mathrm{Co}(\mathrm{II}), \mathrm{Ni}(\mathrm{II})$ and $\mathrm{Cu}(\mathrm{II})$ metals. ${ }^{5}$ Incorporating a pyridine ring into the macrocyclic skeleton leads to a more rigid macro-ring and may alter the strength and selectivity of ligand interaction with a cation. Thus an 18-membered pyridine-diamide-diester receptor possessing $2 \mathrm{x}$ pyN, and 2x amide $\mathrm{NCH}_{3}$, transports and extracts silver picrate with remarkably high selectivity over alkali, alkaline earth and $\mathrm{Pb}^{2+}$ picrate. ${ }^{6}$ The study of similar interactions between 2,2'bipyridine- based macrocycles containing amide functionality and inorganic or organic cations remains an unexplored area, due to the lack of efficient methods for their synthesis.

We have recently developed a simple route to azathiamacrocycles incorporating the 2,2'bipyridine subunit. ${ }^{7}$ On the basis of this prior experience we have elaborated a synthetic pathway 
leading to 2,2'-bipyridine thiacrown ethers 2a,b and 3a,b (Figure 1) containing bisamide functional groups, using as the key steps: (1) S-transalkylation of 6,6'-bis(methylsulfanyl)-2,2'bipyridines $\quad \mathbf{4 a}$ or 1,1'-bis(methylsulfanyl)-6,6',7,7'-tetrahydro-5H,5H'-3,3'-bicyclopenta[c]pyridine $\mathbf{4 b}$ with ethyl bromoacetate and (2) amidification of the resulting 6,6'bis(ethoxycarbonyl)-methylsulfanyl-2,2'-bipyridines $5 a \quad$ or 1,1'-bis(ethoxycarbonyl)methylsulfanyl-6,6,'7,7'-tetrahydro-5H,5H'-3,3'-bicyclopenta[c]pyridine $\mathbf{5 b}$ with the corresponding diamines 7 and $\mathbf{8}$ (Scheme 1). The reaction sequence presented in Scheme 1 has not been examined before.
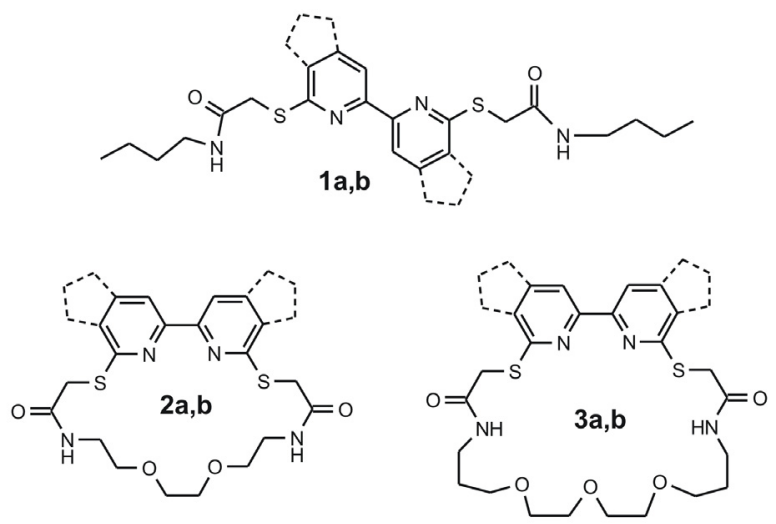

Figure 1. Bipyridines 1a, $\mathbf{b}$ and bipyridine macrocycles $\mathbf{2 a , b}$ and $\mathbf{3 a , b}$ (a denotes monocyclic-, and $\mathbf{b}$ annulated- 2,2'-bipyridine derivatives).

\section{Results and Discussion}

The synthetic pathway leading to macrocycles $\mathbf{2 a , b}$ and 3a,b starts with 2,2'-bipyridine methyl sulfides $\mathbf{4 a}$ and $\mathbf{4 b}$ readily prepared using literature procedures, namely Diels-Alder/retro- DielsAlder reaction of easily accessible 3,3'-bis(methylsulfanyl)-5,5'-bi-1,2,4-triazine with norbornadiene $^{8}$ or 1-pyrrolidino-1-cyclopentene, ${ }^{9}$ respectively. Reactions of $\mathbf{4 a}$ and $\mathbf{4 b}$ with ethyl bromoacetate under non-basic conditions, without solvent, gave S-transalkylated products $\mathbf{5 a}$ and $\mathbf{5 b}$ in excellent yield. ${ }^{7}$ When the reactions were followed by TLC, it was evident in both cases that intermediates were formed which were slowly converted into $\mathbf{5 a}, \mathbf{b}$. With aromatic diesters $\mathbf{5 a}$ and $\mathbf{5 b}$ in hand, we next evaluated their double-amidification reactions with poly(ethylene glycol)diamines $\mathbf{7}$ and $\mathbf{8}$ to the corresponding cyclic bisamides $\mathbf{2 a , b}$ and $\mathbf{3 a , b}$. To establish optimal conditions for the amidification process, reactions of compounds $\mathbf{5 a}$ and $\mathbf{5 b}$ with $\mathbf{n}$ butylamine 6 were first investigated. Treatment of monocyclic diester 5a with n-butylamine in methanol in the presence of ammonium chloride afforded the desired bisamide 1a almost quantitatively. Likewise, amidification of $\mathbf{5 b}$ with n-butylamine gave compound $\mathbf{1 b}$ in good yield 
within 12 hours. The conversion of 2,2'-bipyridine diesters 5a,b into amides 1a,b proceeded gradually via monoamide intermediates, which was noticeable by TLC.
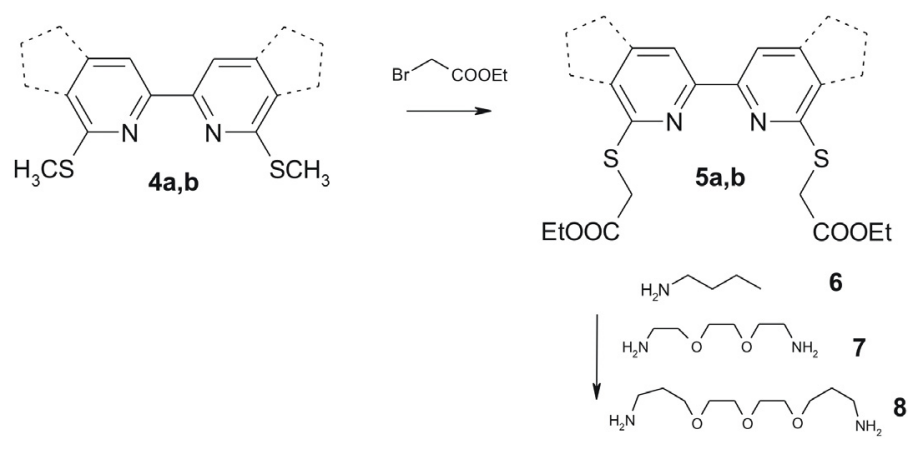

$1 a, b ; 2 a, b ; 3 a, b$

\section{Scheme 1}

The macrocyclization reaction of 5a with diamine 7 was carried out in methanol as solvent under various reaction conditions. In the first case, the reaction was performed under highdilution conditions to avoid unwanted intermolecular side products. After 14 hours' stirring at reflux, the diester 5a was only partly consumed and the product $\mathbf{2 a}$ was isolated in traces. The cyclization protocol was then investigated using 2 mol. equivalents of sodium methoxide in methanol under the same conditions. The presence of sodium ions was expected to give the optimal template effect on the cyclization process. ${ }^{10}$ However, compound 2a was again formed in low yield, which suggests that the template effect of an alkali metal may not be effective in this system. The same procedure was applied for the preparation of compound 3a from $\mathbf{5 a}$ and $\mathbf{8}$. As expected, a similar order of reactivity was observed on treatment of the annulated diester $\mathbf{5 b}$ with diamines $\mathbf{7}$ and $\mathbf{8}$ under high dilution conditions, giving compounds $\mathbf{2 b}$ and $\mathbf{3 b}$ in low yields (Scheme 1). The use of sodium methoxide gives better results, and this method for the preparation of compounds $\mathbf{3 a}, \mathbf{b}$ is recommended. Finally, compound $\mathbf{2 b}$ was obtained in $43 \%$ yield by heating $\mathbf{5 b}$ with diamine 7 at $90^{\circ} \mathrm{C}$ for 10 hours under solvent free conditions.

Evidence for the structures of compounds $\mathbf{1 a}, \mathbf{b}, \mathbf{2} \mathbf{a}, \mathbf{b}$, and $\mathbf{3 a}, \mathbf{b}$ was obtained from ${ }^{1} \mathrm{H}$ - and ${ }^{13} \mathrm{C}$ - NMR, HRMS and elemental analysis. Energy minimization calculations on compounds 2 and 3 were determined using the AM1 semiempirical method ${ }^{11}$ implemented in the program package HyperChem. ${ }^{12}$ The AM1 method was used previously for other molecules containing a 2,2'-bipyridine unit, giving satisfactory results compatible with experimental data. ${ }^{13}$ 

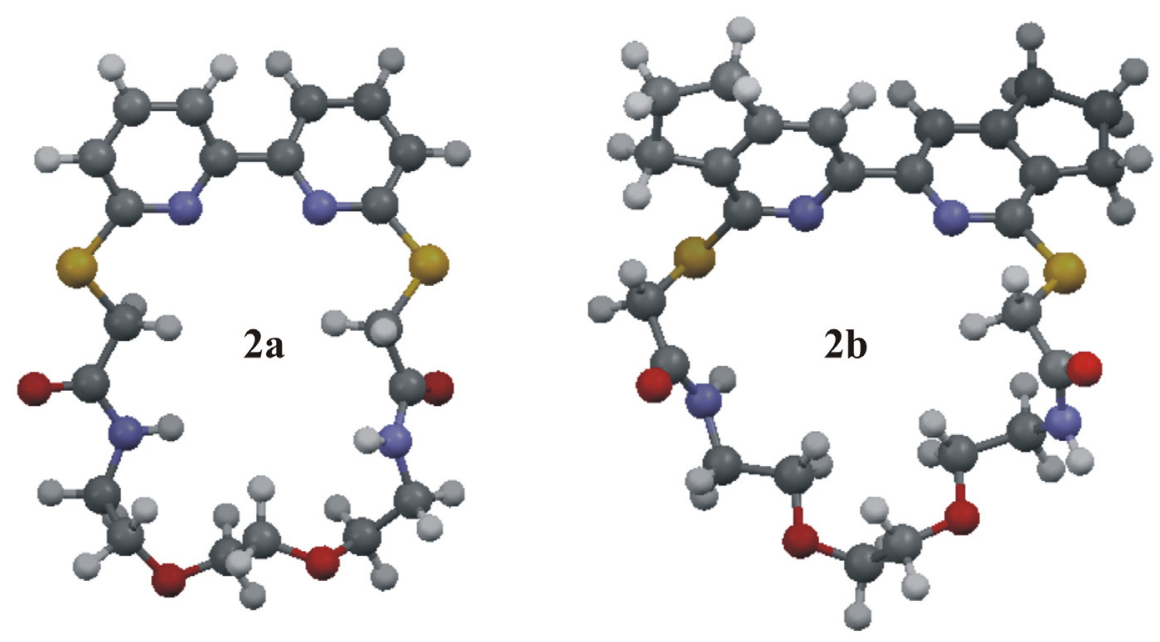

Figure 2. Heats of formation of thiacrown ethers $2 \mathbf{a}:-83.22 \mathrm{kcal} / \mathrm{mol}$ and $\mathbf{2 b}:-103.84 \mathrm{kcal} / \mathrm{mol}$.

Calculations of the heats of formation were performed for macrocycles $\mathbf{2 a}, \mathbf{2} \mathbf{b}, \mathbf{3 a}, \mathbf{3} \mathbf{b}$ and were found to be: $-83.22,-103.84,-136.23$ and $-162.65 \mathrm{kcal} / \mathrm{mol}$, respectively. According to general rules ${ }^{14}$ the lowest heat of formation indicates that the last compound can easily form complexes with small molecules. The presence of additional methylene groups increases the cavity sizes in macrocycles $\mathbf{3 a}$ and $\mathbf{3 b}$. Thus, with regard to size and heat of formation the cavity of macrocycle $\mathbf{3 b}$ is the most promising for the complexation process. The twisted structure of $\mathbf{2 b}\left(-81.74^{\circ}\right)$ (Figure 2) is more wrinkled than the macrocycle 2a $\left(-46.25^{\circ}\right)$ (Figure 2). The same dependence is observed for compounds $3 \mathbf{a}\left(+32.16^{\circ}\right)$ and $\mathbf{3 b}\left(-64.59^{\circ}\right)$ (Figure 3$)$. The reason for the more twisted structures $\mathbf{2} \mathbf{b}$ and $\mathbf{3 b}$ compared to $\mathbf{2 a}$ and $\mathbf{3 a}$ is probably the presence of annulated cyclopentene rings.
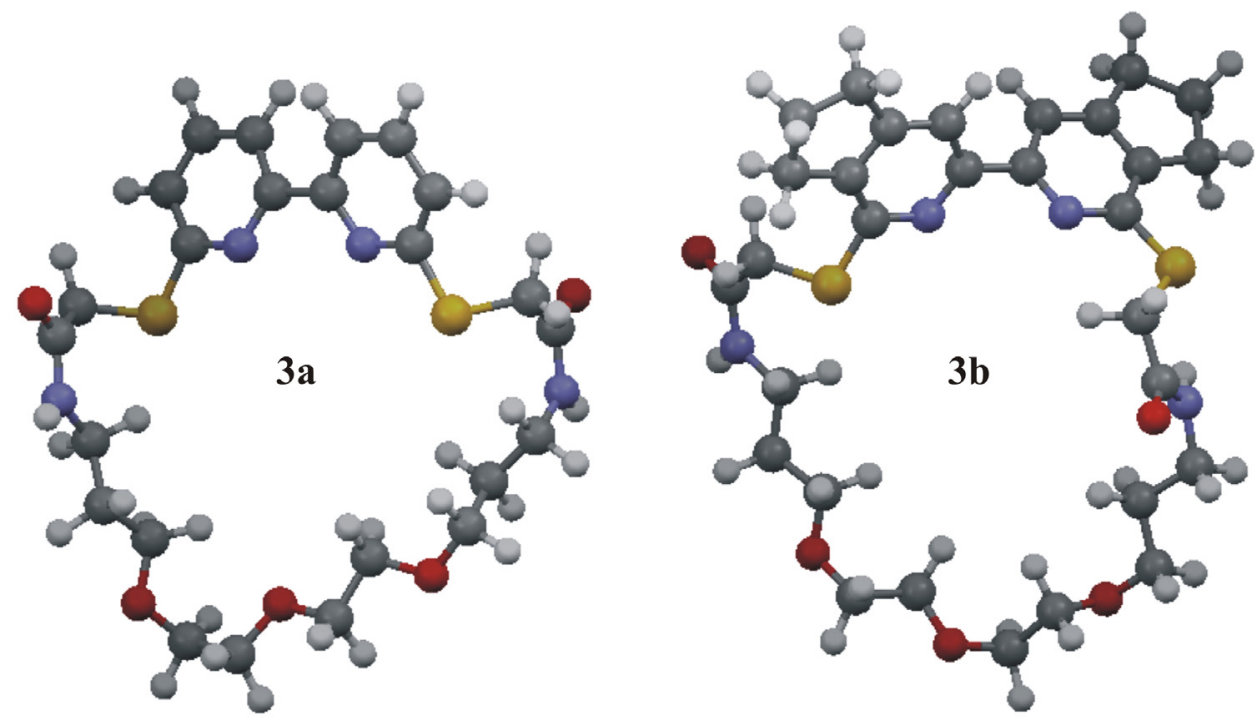

Figure 3. Heats of formation of thiacrown ethers 3a: $-136.23 \mathrm{kcal} / \mathrm{mol}$ and $\mathbf{3 b}:-162.65 \mathrm{kcal} / \mathrm{mol}$. 


\section{Conclusions}

In conclusion, we have demonstrated the first successful approach to 2,2'-bipyridine thiacrown ethers containing bisamide functional groups. Applications of these systems as chelating ligands are in progress.

\section{Experimental Section}

General Procedures. Reactions were monitored by TLC using precoated silica gel or alumina plates containing a fluorescent indicator. Detection was by UV $(254 \mathrm{~nm})$. Melting points were determined with a hot-stage microscope and are uncorrected. Column chromatography was performed on silica gel (Merck 60, 70-230 mesh). ${ }^{1} \mathrm{H}$ - NMR spectra were measured on a Varian Gemini $(200 \mathrm{MHz})$ spectrometer using tetramethylsilane as internal standard. Mass-spectra were measured on an AMD 604 spectrometer. The IR spectra were recorded on a Nicolet Impact 400 D spectrometer.

Synthesis of the bisamide $N$-butyl-6,6'-carbamoylmethylsulfanyl-2,2'-bipyridine (1a). A stirred solution of $5 \mathbf{a}(392 \mathrm{mg}, 1.0 \mathrm{mmol})$ in n-butylamine $(2.5 \mathrm{ml})$ with catalytic amounts of $\mathrm{NH}_{4} \mathrm{Cl}$ was heated under reflux for $10 \mathrm{~h}$. After this time the reaction mixture was cooled and the precipitate 1a was filtered off, and the crude product was crystallized from methanol, to provide $423 \mathrm{mg}$ of $1 \mathrm{a}(95 \%)$. mp $207-217{ }^{\circ} \mathrm{C} ;{ }^{1} \mathrm{H}$ NMR $\left(\mathrm{CDCl}_{3}\right) \delta: 0.67(\mathrm{t}, 3 \mathrm{H}, J=7.5 \mathrm{~Hz}), 1.1-1.12(\mathrm{~m}$, 2H), 1.2-1.4 (m, 2H), 3.15 (q, 2H, $J=6.5 \mathrm{~Hz}), 3.9(\mathrm{~s}, 2 \mathrm{H}), 7.3(\mathrm{dd}, 1 \mathrm{H}, J=0.8, J=7.7 \mathrm{~Hz}) ; 7.7(\mathrm{t}$, $1 \mathrm{H}, J=7.7 \mathrm{~Hz}), 8.2(\mathrm{dd}, 1 \mathrm{H}, J=0.8, J=7.7 \mathrm{~Hz})$. IR $(\mathrm{KBr}) 3298,1650 \mathrm{~cm}^{-1}$. Anal. Calcd for $\mathrm{C}_{22} \mathrm{H}_{30} \mathrm{~N}_{4} \mathrm{~S}_{2} \mathrm{O}_{2}$ : C, 59.16; H, 6.77; N, 12.54. Found C, 59.29; H, 6.81; N, $12.42 \%$.

Synthesis of the bisamide $\mathrm{N}$-butyl-1,1'-carbamoylmethylsulfanyl-6,6',7,7'-tetrahydro-5 $\mathrm{H}$, $\mathbf{5} \boldsymbol{H}^{\prime} \mathbf{- 3 , 3}$ '-bicyclopenta[c]pyridine (1b). A stirred solution of $\mathbf{5 b}(100 \mathrm{mg}, 0.2 \mathrm{mmol})$ in butylamine $(2 \mathrm{ml})$ with catalytic amounts of $\mathrm{NH}_{4} \mathrm{Cl}$ was heated under reflux for $23 \mathrm{~h}$. After this time the reaction mixture was cooled and the precipitate $\mathbf{1 b}$ was filtered off and the crude product was crystallized from methanol, to provide $1 \mathrm{~b}\left(61 \mathrm{mg}, 55 \%\right.$, of. mp $250{ }^{\circ} \mathrm{C} ;{ }^{1} \mathrm{H}$ NMR $\left(\mathrm{CDCl}_{3}\right) \delta: 0.7$ (t, $3 \mathrm{H}, J=7.0 \mathrm{~Hz}$ ), 1.0-1.15 (m, 2H), 1.16-1.30 (m, 2H), 2.20 (quint., $2 \mathrm{H}, J=7.5$ $\mathrm{Hz}), 2.87$ (t, 2H, $J=7.4 \mathrm{~Hz}$ ), 3.0 (t, 2H, $J=7.4 \mathrm{~Hz}) ; 3.16$ (q, 2H, $J=6.2 \mathrm{~Hz}), 3.9$ (s, 2H), 8.02 (s, 1H). IR (KBr) cm ${ }^{-1}: 3298,1655$. Anal. Calcd for $\mathrm{C}_{28} \mathrm{H}_{38} \mathrm{~N}_{4} \mathrm{~S}_{2} \mathrm{O}_{2}: \mathrm{C}, 63.84 ; \mathrm{H}, 7.27 ; \mathrm{N}, 10.64$. Found: C, 63.80; H, 7.23; N, 10.55\%.

13,16-dioxa-7,22-dithia-10,19,27,28-tetraza-tricyclo[21.3.1.1 ${ }^{2,6}$ ]octacosa-1(27),2(28),35,23,25 -hexane-9,20-dione (2a). A stirred solution of 5a (250 mg, $0.64 \mathrm{mmol})$ and 2,2'(ethylenedioxy)-bis(ethylamine) $7(0.09 \mathrm{~g}, 0.64 \mathrm{mmol})$ in anhydrous methanol $(50 \mathrm{ml})$ and $0.11 \mathrm{~g}$ sodium was heated under reflux for $14 \mathrm{~h}$. The reaction mixture was then cooled and the precipitate 2a was filtered off, and the crude product purified by column chromatography using $\mathrm{CH}_{2} \mathrm{Cl}_{2}$-acetone (1:1), to provide 2a (52 mg, 19\%). Mp $206{ }^{\circ} \mathrm{C} ;{ }^{1} \mathrm{H} \mathrm{NMR}\left(\mathrm{CDCl}_{3}\right) \delta 3.45(\mathrm{t}, 2 \mathrm{H}$, 
$J=6.2 \mathrm{~Hz}), 3.75(\mathrm{t}, 2 \mathrm{H}, J=6.2 \mathrm{~Hz}), 4.10(\mathrm{t}, 2 \mathrm{H}, J=7.2 \mathrm{~Hz}), 5.95(\mathrm{~s}, 2 \mathrm{H}), 7.45(\mathrm{dd}, 1 \mathrm{H}, J=0.8$, $7.8 \mathrm{~Hz}), 7.6(\mathrm{t}, 1 \mathrm{H}, J=7.6 \mathrm{~Hz}), 7.8(\mathrm{~d}, 1 \mathrm{H}, J=0.9,7.8 \mathrm{~Hz}) . \mathrm{IR}(\mathrm{KBr}) \mathrm{cm}^{-1}: 3327,1650,1135$. Calcd for $\mathrm{C}_{20} \mathrm{H}_{24} \mathrm{~N}_{4} \mathrm{~S}_{2} \mathrm{O}_{4}$ : C, 53.55; H, 5.39, N, 12.49. Found C, 53.64; H, 5.41, N, 12.75\%.

\section{6,19-Dioxo-10,25-dithia-13,22,27,28-tetraza-pentacyclo- $\left[21,6,1,0^{4,8,26,31}\right]$-tetratriaconta-} 1(33),2(34),3 8,26,31-hexaene-12,23-dione (2b). A stirred solution of $\mathbf{5 b}$ (84 $\mathrm{mg}, 0.18 \mathrm{mmol})$ in 2,2'-(ethylenedioxy)-bis-(ethylamine) $7(0.03 \mathrm{~g}, 0.2 \mathrm{mmol})$ without any additives was heated at $90^{\circ} \mathrm{C}$ for $10 \mathrm{~h}$. The reaction mixture was then cooled and the precipitate $\mathbf{2} \mathbf{b}$ was filtered off and the crude product crystallized from dichloromethane, to provide $2 \mathbf{b}(40 \mathrm{mg}, 43 \%)$. mp $176{ }^{\circ} \mathrm{C}$; ${ }^{1} \mathrm{H}$ NMR ( $\left.\mathrm{CF}_{3} \mathrm{COOD}\right) \delta$ : 0.67 (brs, 2H), 2.85 (brs, 2H), 3.10 (brs, 2H), 3.45 (brs, 4H), 3.75 (brs, 2H), 4.15(s, 2H), 8.10(s, 1H). ${ }^{13} \mathrm{C}$ NMR $\left(\mathrm{CDCl}_{3}\right) \delta: 25.17,30.91,33.99,40.76,67.46,70.21$, 70.78, 115.82, 139.14, 152.25, 154.35, 157.23, 172.26. IR (KBr) cm ${ }^{-1}: 3298,1650,1113$. HRMS Calcd. for $\mathrm{C}_{26} \mathrm{H}_{32} \mathrm{~N}_{4} \mathrm{~S}_{2} \mathrm{O}_{4}$ : 528.1877. Found: $528.1865\left[\mathrm{M}^{+}\right]$. Anal. Calcd for $\mathrm{C}_{26} \mathrm{H}_{32} \mathrm{~N}_{4} \mathrm{~S}_{2} \mathrm{O}_{4}$ : C, 59.09; H, 6.06; N, 10.61. Found C, 59.25; H, 5.74; N, 10.03\%.

\section{4,17,20-Trioxa-7,27-dithia-10,24,32,33-tetraza-tricyclo-[26.3.1.1 $\left.{ }^{2,6}\right]$-tritriaconta-} 1(32),2(33),3,5,28,30- hexaene-9,25-dione (3a). A stirred solution of 5a (250 mg, $0.64 \mathrm{mmol})$ and 4,7,10-trioxo-1,13-tridecadiamine $8(0.125 \mathrm{~g}, 0.64 \mathrm{mmol})$ in anhydrous methanol $(10 \mathrm{ml})$ and sodium $(0.023 \mathrm{~g})$ was heated under reflux for $12 \mathrm{~h}$. After this time the reaction mixture was cooled and the precipitate 3a was filtered off, and the crude product purified by column chromatography $\left(\mathrm{CH}_{2} \mathrm{Cl}_{2}\right.$-acetone $(1: 1)$, to provide 3a $\left(43 \mathrm{mg}, 17 \%, \mathrm{mp} 157{ }^{\circ} \mathrm{C} .{ }^{1} \mathrm{H} \mathrm{NMR}\right.$ $\left(\mathrm{CDCl}_{3}\right) \delta: 1.45(\mathrm{t}, 2 \mathrm{H}, J=7.6), 3.05-3.209(\mathrm{~m}, 8 \mathrm{H}), 3.95(\mathrm{~s}, 2 \mathrm{H}), 7.25(\mathrm{~d}, 1 \mathrm{H}, J=7.6 \mathrm{~Hz}), 7.75$ $(\mathrm{t}, 1 \mathrm{H}, J=7.6 \mathrm{~Hz}), 8.20(\mathrm{~d}, 1 \mathrm{H}, J=7.8 \mathrm{~Hz}) .{ }^{13} \mathrm{C} \mathrm{NMR}\left(\mathrm{CDCl}_{3}\right) \delta: 29.4,34.6,69.6,70.2,70.4$, $70.5,101.3,118.2,122.9,138.2,156.9,169.0$. IR (KBr): 3291, 1648, $1140 \mathrm{~cm}^{-1}$. Anal. Calcd for $\mathrm{C}_{24} \mathrm{H}_{32} \mathrm{~S}_{2} \mathrm{O}_{5}$ : C, 55.38; H, 6.19. Found: C, 55.25; H, 5.86\%.

17,20,23-Trioxa-10,30-dithia-13,27,38,39-tetraaza-pentacyclo $\left[21,6,1,0^{4,8,32,36}\right]$ nonatriaconta1(38),2(39),3,8,31,36-hexaene-12,28-dione (3b). A stirred solution of $5 \mathbf{b}$ (236 mg, $0.5 \mathrm{mmol})$ and 4,7,10-trioxo-1,13-tridecadiamine $8(0.11 \mathrm{~g}, 0.5 \mathrm{mmol})$ in anhydrous methanol $(10 \mathrm{ml})$ and $0.023 \mathrm{~g}$ sodium was heated under reflux for $21 \mathrm{~h}$. The reaction mixture was then cooled and the precipitate $\mathbf{3 b}$ filtered off, and the crude product purified by column chromatography using the mixture $\mathrm{CH}_{2} \mathrm{Cl}_{2}$ : acetone $(1: 1)$, to provide $3 \mathbf{b}(57 \mathrm{mg}, 19 \%)$, mp 193-194 ${ }^{\circ} \mathrm{C} .{ }^{1} \mathrm{H} \mathrm{NMR}\left(\mathrm{CDCl}_{3}\right)$ $\delta: 1.22($ br s, 2H), $1.60(\mathrm{t}, 2 \mathrm{H}, J=6.2 \mathrm{~Hz}), 2.18(\mathrm{q}, 2 \mathrm{H}, J=6.2 \mathrm{~Hz}), 2.86(\mathrm{t}, 2 \mathrm{H}, J=7.4), 3.02(\mathrm{t}$, $2 \mathrm{H}, J=7.8 \mathrm{~Hz}), 3.18-3.40$ (m, 6H), 3.96 (s, 2H), 8.04 (s, 1H). IR (KBr): 3312, 1648, $1122 \mathrm{~cm}^{-1}$. Calcd for $\mathrm{C}_{30} \mathrm{H}_{40} \mathrm{~S}_{2} \mathrm{O}_{5} .2 .6 \mathrm{H}_{2} \mathrm{O}$ : C, 55.66; H, 6.99, N, 8.65. Found: C, 55.67 H, 6.46, N, 8.22\%.

\section{References}

1. Part 44 of "1,2,4-Triazines in Organic Synthesis". For Part 43, see Ławecka, J.; Branowska, D.; Karczmarzyk, Z.; Rykowski, A. Heterocycles 2009, 78, 457.

2. Balzani, V; Bergamini, G.; Marchioni, F.; Ceroni, P. Coord. Chem. Rev. 2006, 250, 1254. Chelucci, G.; Thummel, R. P. Chem. Rev. 2002, 102, 3129. Kaes, C.; Katz, A.; Hosseini, M. 
W. Chem. Rev. 2000, 100, 3553. Lehn, J.-M. Supramolecular Chemistry, Conspects and Perspectives; VCH: Weinheim, 1995.

3. Bradshaw, J. S.; Izatt, R. M.; Bordunov, A.; Zhu, C. Y.; Hathway, J. K. In Comprehensive Supramolecular Chemistry; Goekel, G. W., Ed.; Pergamon: New York, 1996. Weber, E.; Vögtle, F. In Comprehensive Supramolecular Chemistry; Vögtle, F., Ed.; Pergamon: New York, 1996; 2.

4. Rajakumar, P. Mohammed, A. R.; Balu, P. M.; Murugesan, K. Biol. \& Med. Chem. 2006, 14, 7458.

5. Kimura E.; Kurogi, Y.; Wada, S.; Shionaya, M. J. Chem. Soc., Chem. Commun. 1989, 781.

6. Kumar, S.; Hundel, M. S.; Kaur, N.; Singh, R.; Singh, H.; Hundd, G.; Ripoll, M. M.; Aparicio, J. S. Tetrahedron Lett. 1995, 36, 9543.

7. Branowska, D.; Buczek, I.; Kalińska, K. Nowaczyk, J.; Rykowski, A.; Tetrahedron Lett. 2005, 46, 8539.

8. Branowska, D. Molecules 2005, 10, 265.

9. Branowska, D. Synthesis 2003, 2096.

10. Gryko, D. T.; Gryko, D.; Jurczak, J. Synlett 1999, 8, 1310.

11. Dewar, M. J. S.; Zoebish, E. G.; Healy, E. F.; Stewart, J. P. J. Am. Chem. Soc. 1985, 107, 3902.

12. HYPERCHEM, rel. 4,5, Hypercube Inc., Waterloo, Ont., Canada, 1998.

13. Branowska, D.; Rykowski, A. Synlett, 2002, 11, 1892; Branowska, D. Molecules 2005, 10, 856.

14. Rajakumar, P; Srisailas, M; Kanagalatha, R. Tetrahedron 2003, 59, 5365. 